\title{
The Expression in Eukaryotes of a Tyrosine Kinase Which is Reactive with pp60 ${ }^{\text {vsrc }}$ Antibodies
}

\author{
Manfred Schartl ${ }^{1}$ and Angelika Barnekow ${ }^{2}$ \\ ${ }^{1}$ Genetisches Institut der Justus-Liebig-Universităt Gießen, Heinrich-Buff-Ring 58-62, D-6300 Gießen, \\ Federal Republic of Germany \\ ${ }^{2}$ Institut für Virologic, Fachbereich Humanmedizin der Justus-Liebig-Universităt Gießen, Frankfurter Str. 107, D-6300 Gießen, \\ Federal Republic of Germany
}

\begin{abstract}
All specimens of Eumetazoa and Parazoa, ranging from mammals, birds, teleosts, sharks, lampreys, amphioxus, insects, down to sponges showed the pp $60^{\mathrm{c}-\mathrm{sec}}$ associated kinase activity, indicating that $c-s r c$, which is the cellular homologue of the oncogene $v$-src of Rous sarcoma virus (RSV) is probably present in all multicellular animals. Protozoa and plants did not show pp60-err kinase activity.

The degree of $c$-src expression depends on the taxonomic rank of the Eumetazoa tested, and is organ-specific with nervous tissues displaying the highest kinase activities. In the central nervous system of mammals and birds we found a high c-src expression, and in that of the lampreys, amphioxus, and insects the lowest. Unexpectedly, total extracts of sponges showed an amount of $\mathrm{pp} 60^{\mathrm{c}-\mathrm{ere}}$ kinase activity similar to that of brain cell extracts of mammals and birds. These findings suggest that $p p 60^{\mathrm{c}-\mathrm{erc}}$ is a phylogenetic old protein that might have evolved together with the multicellular organisation of Metazoa, and that might be of importance in proliferation and differentiation of nontransformed cells.
\end{abstract}

\section{Introduction}

The detection of cellular oncogenes (c-onc), which are homologous to the transforming genes of RNA tumor viruses (v-onc), has stimulated experimental research about the function of $c$-onc and the origin of $v$-onc. The system best investigated, both biologically and biochemically, is that of the Rous sarcoma virus (RSV), which contains the oncogene $v$-src. The corresponding cellular gene $(c-s r c)$ was detected by molecular hybridisation studies [36]. It was shown that nucleotide sequences homologous to $v$-src are present in the genome of all animals tested, including human, calf, mouse, chicken, salmon, Xiphophorus, and Drosophila melanogaster $[12,19,26,33,35-38]$. Both the v-src and the $c$-src code for $a \mathrm{M}_{\mathrm{r}} 60,000$ molecular weight phosphoprotein (pp60 $60^{n-m e}$ and pp60e-rec, respectively), which has an associated tyrosine kinase activity $[7,9-11,13,18,23,25,27-29$, 32]. Until now, the presence of $\mathrm{pp} 60^{\mathrm{serr}}$ and its kinase activity has been demonstrated in a variety of mammals, birds, in the frog Xenopus, and in 10 closely related species of poeciliid fish $[2,25,29,31]$.

In the course of a study on the expression and function of $c$-src in normal cells, we have found recently an increased expression of the cellular src gene during early embryogene- sis $[3,6]$. Furthermore, an organ-specific expression of $c$-src could be demonstrated in adult fish, chicken, and mammals showing decreased activity in muscle but a relatively high activity in brain extracts $[2,5]$. In an extension of these studies we have now investigated the expression of $c$-src by determining the pp60-arc kinase activity in organisms that represent the different taxonomic groups of eukaryotes. On this basis we present evidence that c-src might be present and expressed in many or all Metazoa, appearing first during phylogenesis in the sponges.

The common method to assay pp $60^{\mathrm{s}-\mathrm{m}}$ kinase activity is based on the discovery that the heavy chain of immunoglobulin G from RSV-tumor-bearing rabbit (TBR) sera is phosphorylated in tyrosine, when the pp60 immunoprecipitate is incubated with $\gamma^{32}$ P-ATP $[3,10,29]$. Since the $v$-src gene actually encodes the tyrosine-specific protein kinase [15], the detection of pp60 as a measure for the expression of the viral src gene. Accordingly, as already shown in the chicken system $[3,6]$, our studies assumed that the cellular pp60 $60^{\text {senc }}$ kinase activity reflects in every organism the presence and expression of the cellular src gene.

\section{Methods}

\section{Materials}

The following organisms were used in this study: Laboratory rat (Rattus rattus, Wistar strain); laboratory mouse (Mus domesticus, BALB/c strain); chicken (Gallus domesticus, Spafas white leghorn strain); Japanese quail (Coturnix coturnix, breeding stock); flatfish (Pleuronectes platessa/Platichthyes flesus, Pleuronectidae); sea robin (Trigla lucerna, Triglidae); European roach (Leuciscus rutilus, Cyprinidae); river gudgeon (Gobio gobio, Cyprinidae); swordtail (Xiphophorus helleri, Poeciliidae); codfish (Gadus morhua, Gadidae); black striped cichlid (Cichlasoma nigrofasciata, Cichlidae); cat shark (Scyliorhinus caniculus, Selachii); western brook lamprey (Lampetra planeri, Petromyzoniidae); Amphioxus (Branchiostoma lanceolatum); cockroach (Periplaneta americana, Blattopteroidea); rotifer (Epiphanes senta); sea-anemone (Alcyonum digitatium, Anthozoa); marine sponge (Halichondria panicea, Desmospongiae); freshwater sponge (Spongilla lacustris, Desmopongiae); Trichoplax adhaerens; Cryptomonas spec.; Chlorogonium spec.; Euglena gracilis; Volvox tertius; Paramecium bursaria; Tetrahymena thermophila; red sea-weed (Porphyridium cruen- 
tum, Rhodophyceae); tomato (Lycopersicon esculentum 'Cultivar Tropic', Solanaceae).

\section{Cells and Viruses}

Chicken embryo cells (CEC) were prepared from 8-day-old embryos and maintained in Dulbecco's modified Eagle medium (Flow laboratories, Federal Republic of Germany) containing $5 \%$ calf serum. Secondary cells were infected with cloned virus of the Schmidt-Ruppin A strain of RSV (SR-1).

\section{Sera}

Antisera were prepared from normal rabbits and from RSV-tumor bearing rabbits (TBR-serum). Tumors were induced in newborn rabbits by simultaneous injection of Schmidt-Ruppin D strain and Prague $C$ strain of RSV in a modification [39] of the procedure described by Brugge and Erikson [7].

\section{Specifity of the Antiserum}

Pp60-are can be detected by using antibodies originally prepared for the study of the viral-transforming protein, pp60 6 -src. In these studies a TBR-serum (H6) was used, whose antibodies were able to react with the viral as well as the cellular pp60erc (Fig. 1), and which was applied in excess amounts.

\section{Radioactive Labeling of Cells and Preparation of Cell and Tissue Extracts}

Cells $\left(10^{7}\right)$ were radiolabeled for $4 \mathrm{~h}$ in $5 \mathrm{ml}$ phosphate-free medium containing ${ }^{32} \mathrm{P}$-orthophosphate $(1 \mathrm{mCi} / \mathrm{ml}$ ) (Amersham Ltd., United Kingdom). At the end of the labeling period, cells were washed twice with cold phosphate buffered saline (PBS) and scraped into $1 \mathrm{ml}$ extraction buffer (10 mM sodium phosphate, $40 \mathrm{mM} \mathrm{NaF}, 10 \mathrm{mM}$ EDTA, $1 \%$ Triton X-100, and 5\% Trasylol (Bayer, Leverkusen, Federal Republic of Germany) as protease inhibitor, with a rubber policeman. Tissue samples, Protozoa, and sponges were homogenized in the same buffer using a tightly fitting Dounce homogenizer $\left(10\right.$ strokes at $\left.4^{\circ} \mathrm{C}\right)$. All subsequent steps were performed at $4^{\circ} \mathrm{C}$. Cells were centrifuged for $30 \mathrm{~min}$ at $6,000 \times g$ and then used immediately for immunoprecipitation. The clarified supernatants were incubated with $5 \mu \mathrm{l}$ of TBR serum for $60 \mathrm{~min}$. A $10 \%$ suspension of formaline-fixed Staphylococcus aureus [7] prewashed three times was added to absorb the immunocomplexes. After $30 \mathrm{~min}$ the immunocomplexes were centrifuged for $2 \mathrm{~min}$ in an Eppendorf centrifuge, washed twice with $1 \mathrm{ml}$ kinase washing buffer $(10 \mathrm{mM}$ sodium phosphate, $40 \mathrm{mM}$ $\mathrm{NaF}, 10 \mathrm{mM}$ EDTA, 0,2\% Triton X-100, $1 \mathrm{M} \mathrm{NaCl}$ ), and washed once with $1 \mathrm{ml}$ water. Labeled samples were washed four times with kinase washing buffer and once with water, and the pellet was then resuspended in $30 \mu \mathrm{l}$ of sample buffer ( $2 \%$ sodium dodecyl sulfate, $10 \%$ glycerol, $0.08 \mathrm{M}$ Tris (pH 6.8), 2\% mercaptoethanol, $0.02 \% 3^{\prime} 3^{\prime \prime} 5^{\prime} 5^{\prime \prime}$-tetrabromophenol sulfonepthalein). This mixture was boiled for $2 \mathrm{~min}$ and centrifuged for $2 \mathrm{~min}$ at $10,000 \times g$ and the supernatant was loaded onto a $11 \%$ acrylamide slab gel with a $2.5 \%$ acrylamide stacking gel [22]. The labeled proteins were detected by autoradiography after staining, destaining,
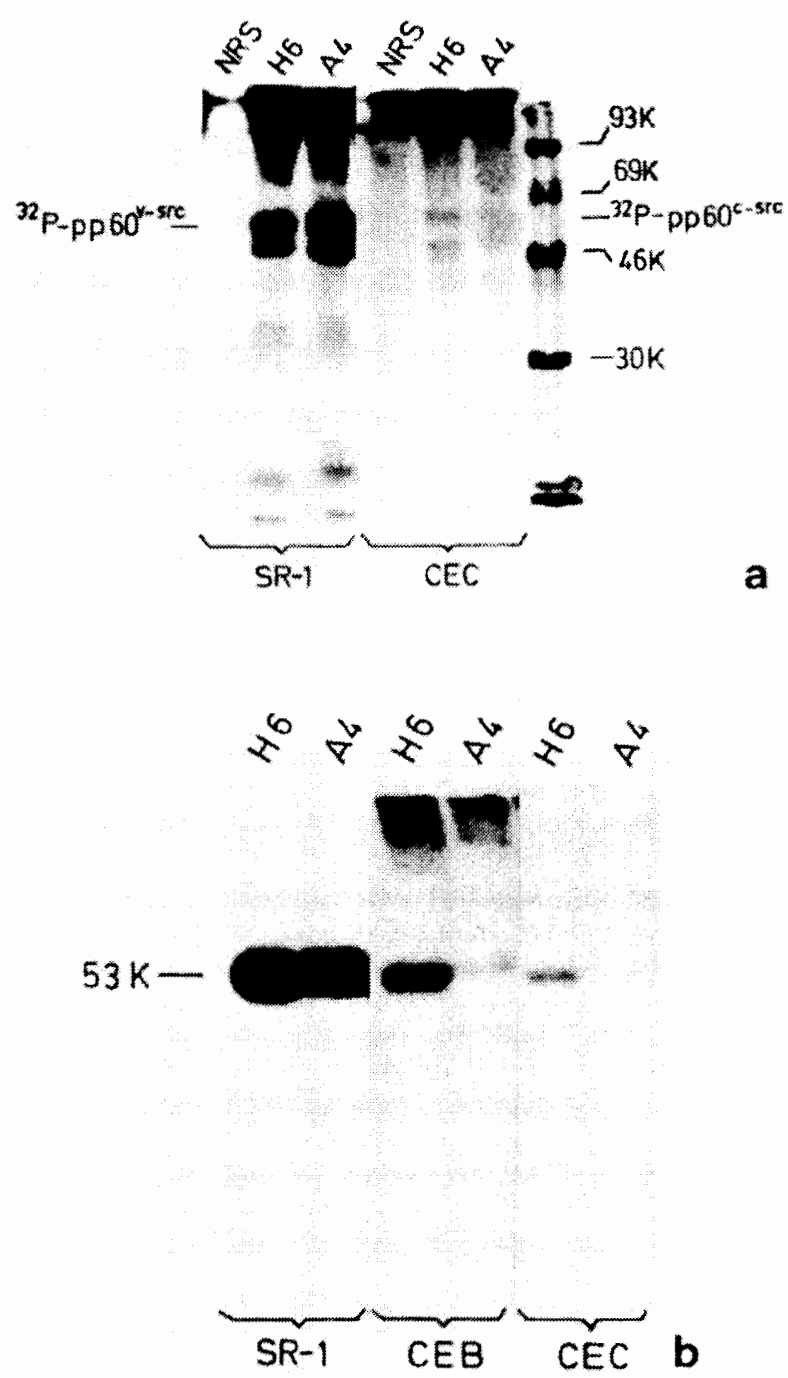

Fig. 1. Characterization and specificity of the TBR-serum used in this study. Extracts of ${ }^{32}$ P-labeled RSV-Schmidt-Rupin A infected chicken embryo cells (SR-1) and of uninfected ${ }^{32}$-labeled chicken embryo cells (CEC), immunoprecipitated with normal rabbit serum (NRS) and two different TBR-sera (H6, A4) and separated on $11 \%$ polyacrylamide gel. Note: While serum A4 only

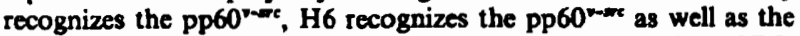
pp60 $60^{-m}$. b Kinase assay from immunoprecipitates of SR-1, CEC, and chicken embryo brain extracts with $\mathrm{H} 6$ and $\mathrm{A} 4$ serum. Immunocomplexes were separated on a $11 \%$ polyacrylamide gel. 53K indicates the heavy chain of the anti-pp60 immunoglobulin

and drying of the gels. The molecular weight of the proteins on the gels was determined using ${ }^{14} \mathrm{C}$-labeled protein markers (Amersham Ltd., United Kingdom) and ${ }^{32} \mathrm{P}$. labeled heavy chain of IgG. For quantitation, the radioactive gel bands were cut out and solubilized, and their radioactivity was determined by liquid scintillation counting.

\section{Protein Kinase Assay}

The protein kinase assay was performed according to the method of Collett and Erikson [9], except that the incubation was at $4^{\circ} \mathrm{C}$. Maximum ${ }^{32} \mathrm{P}$ incorporation occurred between 3-6 $\mathrm{min}$ [25]. Therefore all kinase assays were per- 
formed with an incubation time of $5 \mathrm{~min}$. Protein A-bound immunoprecipitates from unlabeled cell extracts were prepared as described above and suspended in $10 \mu$ of kinase buffer (20 mM 1,3-bis tris[(hydroxymethyl) methylamino] propane, $50 \mathrm{mM} \mathrm{MgCl}, \mathrm{pH} 6.8$ ) and $10 \mu \mathrm{l}$ of approximately $0.1 \mu \mathrm{M}\left[\gamma^{32} \mathrm{P}\right] \mathrm{ATP}(>2,000 \mathrm{Ci} / \mathrm{mmol}$, Amersham Ltd., United Kingdom) in $50 \mu$ lof kinase buffer were added to each sample. The reaction was stopped by adding $1 \mathrm{ml}$ quench buffer [ $100 \mathrm{mM}$ sodium phosphate, $10 \mathrm{mM}$ EDTA, $40 \mathrm{mM} \mathrm{NaF}, 1 \mathrm{mM}$ ATP (pH 7.0)] to the samples, and the labeled immunocomplexes were processed for gel electrophoresis as described above. The extracts were assayed for protein content. Equal amounts of protein were loaded for each sample. Autoradiography and determination of radioactivity in the heavy chain of $\mathrm{IgG}$ were performed in parallel for each sample. To confirm that the ${ }^{32} \mathrm{P}$-labeled 53,000 band was indeed heavy chain IgG, aliquots of various samples were run under nonreducing conditions and the majority of ${ }^{32} \mathrm{P}$ counts was detected in a high molecular weight band of $>150,000$.

\section{Protein Determination}

Determination of protein concentration in a supernatant of the centrifuged cell lysates was carried out on trichloroacetic-precipitated samples according to the method of Lowry et al. [24].

\section{Phosphoamino Acid Analysis}

${ }^{32} \mathrm{P}$-labeled IgG of TBR serum-precipitated immunocomplex of chicken, mouse, or fish extracts was cut out of the gel, eluted from the gel sample, and processed for phosphoamino acid analysis according to the method described by Hunter and Sefton [18] as modified by Ziemiecki et al. [40].

\section{Results}

\section{Identification of pp60s-ere}

In a variety of multicellular animals we detected a protein with kinase activity that reacted with antibodies from tumor-bearing rabbit (TBR) sera directed against pp60 ${ }^{\text {v-mer }}$. The following studies gave further evidence that this protein might be the cellular pp60-src: (a) No kinase activity was found when the immunoprecipitation was done with normal rabbit serum. (b) Phosphoamino acid analysis, which was performed if the kinase activity was at least $500 \mathrm{cpm} / \mathrm{mg}$ protein, e.g., in mouse, chicken, fish, and sponge (Fig. 2), revealed that the phosphorylation site in the $\mathrm{Ig} \mathrm{G}$ was tyrosine. (c) The kinase activity was not inhibited by the unusual nucleotide diadenosine $5, \quad 5^{\prime \prime}-\mathrm{P}^{1} \mathrm{P}^{4}$ tetraphosphate (Ap4A), as investigated in cell extracts of sponge, fish, chicken, and mouse. By this common property the cellular kinase is distinguishable from the viral kinase, which is inhibited by this molecule (Fig. 3) [1,17]. Other nucleotides, like ATP, ADP, GTP, and GDP inhibited both the cellular as well as the viral kinase activity.

\section{Organ Specificity of Expression of pp60 $60^{\text {-sere }}$ Kinase}

In all metazoan organisms, which have developed organ systems, the kinase activity was always especially high in

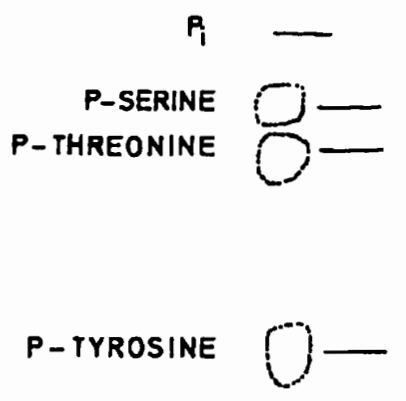

\section{ORIGIN -}

Fig. 2. Identification of phosphoamino acids in phosphorylated immunoglobulin heavy chain of TBR-H6-serum precipitated Halichondria cell extracts and subsequent performance of the kinase assay

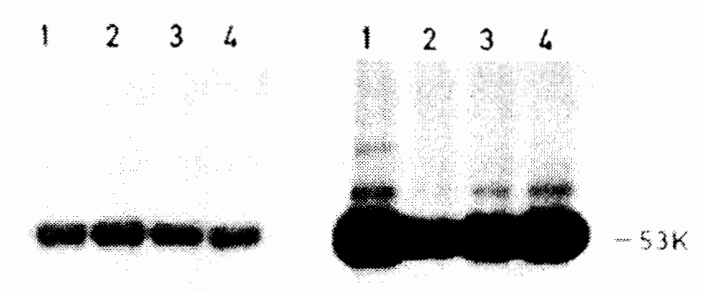

Fig. 3. Effect of Ap4A on the pp60 ame and pp60"-ex kinase activity. Various concentrations of Ap4A were added to the immunoprecipitates $5 \mathrm{~min}$ before the phosphorylation was started. Except for the addition of Ap4A, the kinase assay was performed as described in the Methods section. $1=$ no Ap4A, $2=100 \mu \mathrm{M}$ Ap4A, $3=50 \mu \mathrm{M}$ Ap4A, $4=10 \mu \mathrm{M}$ Ap4A. 53K indicates the heavy chain of the procipitated TBR-immunoglobulin. Determination of ${ }^{32} \mathrm{P}$ counts in 53K of the experiment shown: fish; lane $1=230 \mathrm{cpm}$, lane $2=$ $250 \mathrm{cpm}$, lane $3=240 \mathrm{cpm}$, lane $4=230 \mathrm{cpm}$; SR-1; lane $1=$ $5,000 \mathrm{cpm}$, lane $2=2,000 \mathrm{cpm}$, lane $3=3,000 \mathrm{cpm}$, lane $4=$ $4,000 \mathrm{cpm}$

extracts of nervous systems. Other organs, like liver and spleen, which were investigated in fish, chicken, mouse, and rat, showed kinase activities of about $30-50 \%$ of the activity found in brain cell extracts. Extracts of muscle had no or barely detectable activity (Fig. 4, Table 1). In extracts from whole organisms it was difficult and sometimes impossible to detect the kinase activity.

\section{Distribution of pp60-erc Kinase in Taxonomic Groups of Eukaryotes}

The presence of the $p p 60^{c-a r c}$ kinase was demonstrated in extracts of the central nervous system from mammals, birds, 


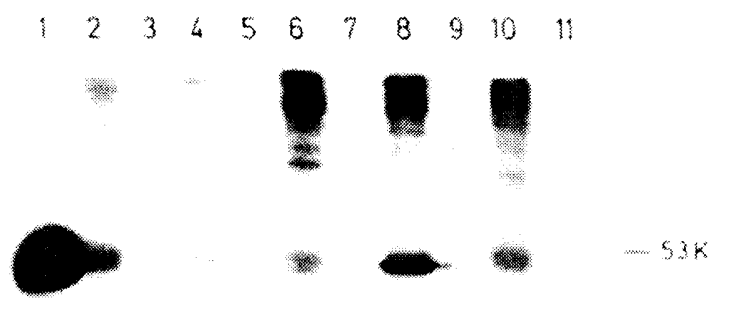

Fig. 4. Demonstration of pp60s-ser kinase activity in sponge and fish. Track 1: Halichondria panicea, total extract; track 2: Scyliorhinus caniculus, brain; track 3: Scyliorhinus caniculus, muscle; track 4: Trachurus trachurus, brain; track 5: Trachurus trachurus, muscle; track 6: Trigla lucerna, brain; track 7: Trigla lucerna, muscle; track 8: Gadus morhua, brain; track 9: Gadus morhua, muscle; track 10: Pleuronectes platessa, brain; track 11: Pleuronectes platessa, muscle. 53K indicates the heavy chain of immunoglobulin $\mathrm{G}$ of the pp60s-ser immunocomplex

bony fish, shark, lamprey, amphioxus, and cockroach. From rotifers and sea-anemones no nerve cell extract could be prepared at present, and only a total extract was tested. These extracts showed no kinase activity. Surprisingly in total extracts of sponges, a pp60 $0^{\mathrm{csoc}}$ kinase activity was detectable.

Comparing the activity of the pp60-arc kinase, measured as ${ }^{32} \mathrm{P}$ incorporation in the pp606-sic immunocomplex, in the nervous systems of various eumetazoans, there is a decrease according to the taxonomic rank (Table 1). Mammals and birds showed values of about $900 \mathrm{cpm} / \mathrm{mg}$ protein, which represents the highest activities, while teleostean fish had $250-600 \mathrm{cpm} / \mathrm{mg}$ protein and sharks $200 \mathrm{cpm} /$ $\mathrm{mg}$ protein. In the lamprey and in the amphioxus, kinase activity was even lower than in fish, i.e., $100 \mathrm{cpm} / \mathrm{mg}$ protein. In invertebrates, in the cerebral ganglion of the cockroach, which is the corresponding organ to the vertebrate brain, kinase activity was similar to lamprey and amphioxus. Unexpectedly in sponges, which represent the most primitive form of metazoan organisation, kinase activity was about $900 \mathrm{cpm} / \mathrm{mg}$ protein, which is as high as in mammals and birds. Gemmulae, the physiologically nearly inactive reproductive buds of sponges have a greatly decreased kinase activity $(100 \mathrm{cpm} / \mathrm{mg}$ protein) compared to the dividing, differentiating, and metabolically active adult form of sponges.

All unicellular eukaryotes tested, including the colonial flagellat Volvox, Euglena, Cryptomonas, Chlorogonium, Paramecium, and Tetrahymena showed no kinase activity. Trichoplax adhaerens, which is regarded to represent an intermediate form between the protozoan and the metazoan organization, also was negative for the tyrosine phosphorylating kinase activity. In the red sea-weed Porphyridium and in the tomato plant, which were investigated as examples from the plant kingdom, no kinase activity was found.

\section{Discussion}

We have investigated the expression of $c$-src in a variety of organisms ranging from primitive multicellular organisms to highly evolved vertebrates. The assay employed was
Table 1. Occurrence of pp60 $60^{\mathrm{cm}}$ kinase activity in Metazoa

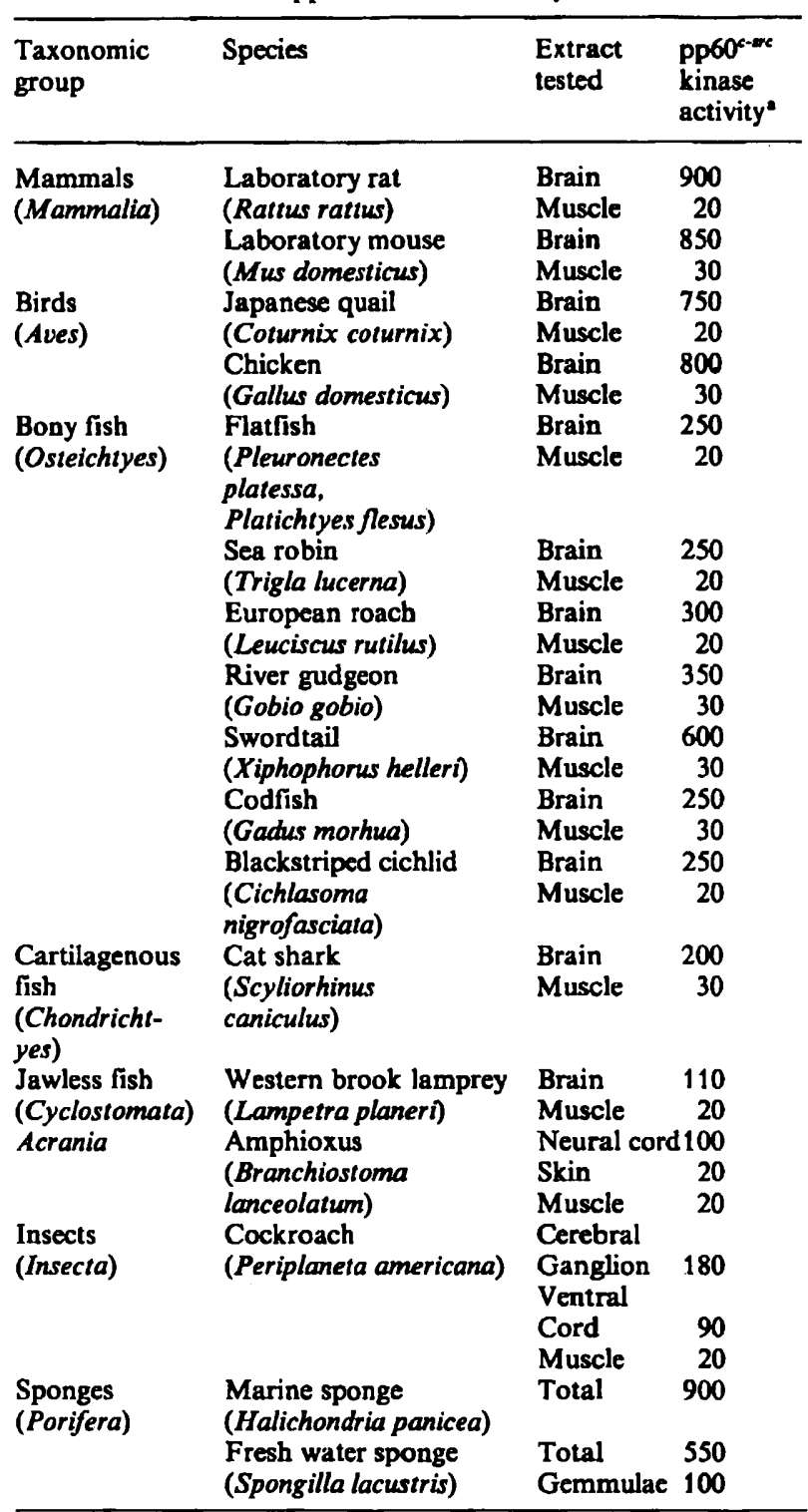

- The $\mathrm{pp} 60^{\mathrm{s}-m e}$ kinase activity was determined with the kinase assay described in the Methods soction and is specified in $\mathrm{cpm} / \mathrm{mg}$ protcin

the quantitation in extracts of these organisms of the tyrosine kinase activity which phosphorylates the IgG of a TBR serum that recognizes the cellular pp60-me. In previous experiments we were able to demonstrate a 60,000 phosphoprotein after immunoprecipitation of ${ }^{32} \mathrm{P}$-labeled extracts of chick embryo fibroblasts, chick embryo brain $[2,5,6]$, fish brain cells [3], and mouse and rat brain cells (unpublished results). In this study we present evidence that also in lower vertebrates and invertebrates, a tyrosine phosphorylating activity can be detected by TBR-serum. For technical reasons, i.e., because the organs investigated could not be labeled with ${ }^{32} \mathrm{P}$-orthophosphate, in the case of animals lower than fish, we had to restrict ourself to the kinase assay and therefore could not demonstrate the pp60 $0^{\text {s-src }}$ protein directly as a 60,000 protein. 
No kinase activity could be detected in unicellular eukaryotes and in plants. Thus, the pp60 $60^{\mathrm{carc}}$ seems to bee a protein typical for the multicellular organisation of metazoans, appearing first during phylogenesis in sponges. As the sponges are known to have evolved in the proterozoikum, the origin of $p p 60^{x-s r c}$ has to be estimated to be over $1.5 \times 10^{9}$ years ago.

The conserved nature of this protein is demonstrated by two characteristics: (1) Antibodies produced by rabbits against the avian viral protein detect the pp60\%-src kinase activity even in sponges. This points to the conservation of at least some antigenic determinants. (2) The pp606-sec from uninfected cells of metazoans displays the activity of a tyrosine-specific kinase, which in contrast to the viral kinase, is not inhibited by Ap4A. This reflects a conservation in function. The difference between the cellular and the viral kinase may be due to the different tyrosine phosphorylation sites in the pp $60^{\text {rese }}$ and the pp60-are [34], which in turn may reflect structural differences between the cellular and viral pp60sre as observed by immunologic means (T. Tamura and H. Bauer, personal communication). The organ-specific expression of $c$-src in all metazoans that have developed organ systems is consistent with our previous data on the organ-specific expression of c-src in fish, with brain desplaying the highest kinase activity of all organs $[2,5]$. The organ-specific $c$-src expression implies a possible explanation for the failure to detect $\mathrm{pp} 60^{\mathrm{c}-\mathrm{sec}}$ kinase activity in coelenterates and rotifers so far. In coelenterates, a nervous cell system is developed as a 'pseudo-organ' comprising less than $5 \%$ of the total cells of the animal. In rotifers the ganglion represents only a minute part of the body. In the present study it was impossible to separate the nerve cells from the other cell types before performing the immunoprecipitation. Thus, an anti-pp $60^{\text {r-src }}$ reactive protein in the nerve cells may be scattered by the nonreactive extracts from other cell types in the extract mixture.

So far, little is known about the possible function of the cellular src gene and its product. The organ specificity of the pp60s-sre, which is obviously conserved in all Metazoa, points to a function in normal cellular metabolism or proliferation, as suggested recently by our group $[3,6]$. On the one hand, high kinase activities in the nervous cell system, which is composed nearly exclusively of nondividing cells, implies that $\mathrm{pp} 60^{\mathrm{cssc}}$ activity is not necessarily related to cell proliferation in every case. On the other hand, low kinase activities in the physiologically inactive and nondividing gemmulae of sponges and high activities in the metabolically active and proliferating adult sponge, support the hypothesis that $\mathrm{pp} 60^{\mathrm{c}-\mathrm{me}}$ might play a role during cell proliferation and differentiation $[3,6]$. In the light of this consideration, the pp60 could be regarded as a multifunctional protein, as shown for the viral protein $[8,14,16]$ and as proposed for the cellular protein [4]. Because of the relationship of the amino acid sequence of pp60 6 more with that of the presumably transforming protein of $\mathrm{Y} 73$ virus [19], which also shows kinase activity [21], we cannot exclude the possibility that in one or the other case it is not pp $60^{\circ-8 r e}$ which is being detected but a kinase activity related to it.

To learn more about the function of cellular oncogenes in cell proliferation and cell differentiation in multicellular animals, the well understood genetic systems and cell physiologic model systems of less complex organisms will be useful.
Acknowledgements. We thank Prof. Dr. F. Anders and Prof. Dr. H. Bauer for many helpful suggestions and for critically reading the manuscript. Thanks are also due to the late Prof. Dr. J. Illies (Max-Planck Institut für Limnologie, Schlitz) for supplying us with living specimen of Lampetra planeri, Prof. Dr. E. Kilian (Giessen) for Spongilla lacustris, Dr. H.M. Seyfert (Giessen) for Tetrahymena thermophila, Dipl.-Biol. J. Steinbiss (Giessen) for Porphyridium cruentum, and Dr. A. Camacho (Giessen) for tomato leaf extract. Stock cultures of Epiphanes, Trichoplax, Votvox, Euglena. Chlorogonium, Cryptomonas, and Paramecium came from the Institut furr Zoologie der Universität Tübingen. We thank Dipl.-Biol. A. Schartl for cooperation. The excellent technical assistance of $E$. Ossendorf, U. Wend, and C. Reitz is gratefully acknowledged. Part of this research was performed in the laboratories of the Biologische Anstalt Helgoland. This work was supported by the Deutsche Forschungsgemeinschaft (Sonderforschungsbereiche 47 "Virologie" and 103 "Zellenergetik und Zelldifferenzierung").

\section{References}

1. Barnekow A (to be published) Effect of several nucleotides on the phosphorylating activities of the Rous sarcoma virus transforming protein $\mathrm{pp} 60^{\text {warc }}$ and its cellular homologue, the pp60e-ser

2. Barnekow A, Bauer H, Boschek CB, Friis RR, Ziemiecki A (1981) Rous sarcoma virus transformation: Action of the src gene product. In: Schweiger HG (ed) International cell biology 1980-1981. Springer-Verlag, Berlin, p 457

3. Barnekow A, Schartl M, Anders F, Bauer H (1982) Identification of a fish protein associated with a kinase activity and related to the Rous sarcoma virus transforming protein. Cancer Res 42:2429

4. Bauer H (1982) Cell transformation by RNA sarcoma virus. In: Nicolini C (ed) Cell growth. Plenum Press, New York, p 653

5. Bauer H, Barnekow A, Boschek CB, Friis RR, Ziemiecki A (1982) The dualism of expression of onc-genes: transformation versus differentiation. In: Jaenicke $L$ (ed) $33^{\text {rd }}$ Mosbacher Colloquium. Springer-Verlag, Berlin, $p 74$

6. Bauer $H$, Barnekow $A$, Rose $G(1982)$ The transforming protein of Rous sarcoma virus, pp60erc; Growth and cell proliferation. In: Dumont JE, Nunez J, Schultz G (eds) Hormones and cell regulation, Vol. 6. Elsevier Biomedical Press, Amsterdam, p 187

7. Brugge JS, Erikson RL (1977) Identification of a transformation-specific antigen induced by avian sarcoma virus. Nature 269:346

8. Calothy G, Pessac B (1976) Growth stimulation of chicken embryo neuroretinal cells infected with RSV - Relationship to viral replication and morphological transformation. Virology $71: 336$

9. Colletl MS, Erikson RL (1978) Protein kinase activity associated with the avian sarcoma virus src gene product. Proc NatJ Acad Sci USA 75:2021

10. Collett MS, Brugge JS, Erikson RL (1978) Characterization of a normal avian cell protein related to the avian sarcoma virus transforming gene product. Cell 15:1363

11. Collett MS, Purchio AF, Erikson RL (1980) Avian sarcoma virus transforming protein, $\mathrm{pp} 60^{\mathrm{N}}$, shows protein kinase activity specific for tyrosine. Nature 285:167

12. Czernilofsky AP, Friis RR, Schartl M (unpublished data)

13. Erikson RL, Collett MS, Erikson E, Purchio AF (1979) Evidence that the avian sarcoma virus transforming product is a cAMP-independent protein-kinase. Proc Natl Acad Sci USA 76:6260

14. Friis RR, Weber MJ (1978) Properties and speculations about the Rous sarcoma virus src gene product. In: Barlati S, de Giuli-Morghen C (eds) Avian RNA tumor viruses. Piccin Medical Books, Padua, p 296

15. Gilmer TM, Erikson RL (1981) Rous Sarcoma virus transform- 
ing protein, pp60 60 , expressed in $E$. coll, functions as a protein kinase. Nature 294:771

16. Gionti E, Kryceve-Martinerie C, Aupoix MC, Calothy G (1980) Phenotypic heterogeneity among temperature sensitive mutants of Rous sarcoma virus. Studies with inhibitors of protein synthesis. Virology 100:219

17. Glossmann H, Presek P, Eigenbrodt E (1981) Association of the src-gene product of Rous sarcoma virus with a pyruvate kinase inactivating factor. Mol Cell Endocrinol 23:49

18. Hunter T, Sefton MB (1980) Transforming gene product of Rous sarcoma virus phosphorylates tyrosine. Proc Natl Acad Sci USA 77:1311

19. Karess RE, Hayward WS, Hanafusa $H$ (1979) Cellular information in the genome of recovered avian sarcoma virus directs the synthesis of transforming protein. Proc Natl Acad Sci USA $76: 3154$

20. Kawai S, Yoshida M, Segawa K, Sugiyama H, Ishizaki R, Toyoshima $K$ (1980) Characterization of $Y 73$, an avian sarcomu virus: A unique transforming gene and its product, a phosphopolyprotein with protein kinase activity. Proc Natl Acad Sci USA 77:6199

21. Kitamura N, Kitamura A, Toyoshima K, Hirayama $\mathbf{Y}$, Yoshida M (1982) Avian sarcoma virus Y73 genome sequence and structural similarity of its transforming gene product to that of Rous sarcoma virus. Nature 297:205

22. Laemmli UK (1970) Cleavage of structural proteins during assembly of the head of bacteriophage $T_{4}$. Nature 227:680

23. Levinson AD, Oppermann H, Levintow L, Varmus HE, Bishop JM (1978) Evidence that the transforming gene of avian sarcoma virus encodes a protein kinase associated with a phosphoprotein. Cell 15:561

24. Lowry OH, Rosebrough NJ, Farr AL, Randall RJ (1951) Protein measurement with the Folin phenol reagent. J Biol Chem 193:265

25. Oppermann H, Levinson AD, Varmus HE, Levintow L, Bishop JM (1979) Uninfected cells contain a protein that is closely related to the product of the avian sarcoma virus transforming gene (src). Proc Natl Acad Sci USA 76:1804

26. Parker RC, Varmus HE, Bishop JM (1981) Cellular homologue (c-src) of the transforming gene of Rous sarcoma virus: Isolation, mapping, and transcriptional analysis of c-src and flanking regions. Proc Natl Acad Sci USA 78:5842

27. Purchio AF, Erikson RL (1977) Translation of $35 S$ and subgenomic regions of avian sarcoma virus RNA. Proc Natl Acad Sci USA 74:4661

28. Purchio AF, Erikson E, Brugge JS, Erikson RL (1978) Identification of a polypeptide encoded by the avian sarcoma virus sre gene. Proc Natl Acad Sci USA 75:1567

29. Rohrschneider LR, Eisenmann RN, Leitch CHR (1979) Identi- fication of a Rous sarcoma virus transformation-related protein in normal avian and mammalian cells. Proc Natl Acad Sci USA 76:4479

30. Rübsamen H, Friis RR, Bauer H (1979) Src gene product from different strains of avian sarcoma virus: Kinetics and possible mechanism of heat inactivation of protein kinase activity from cells infected by transformation-defective, temperature-sensitive mutant, and wild-type virus. Proc Natl Acad Sci USA 76:967

31. Schartl M, Barnekow A, Bauer H, Anders F (1982) Oncogenes in Xiphophorus: A relation in heritability and expression of a tumor gene and the cellular homologue of the Rous sarcoma virus transforming gene. Cancer Res 42:4222

32. Sefton BM, Hunter R, Beemon K (1980) Relationship of polypeptide products of the transforming gene of Rous sarcoma virus and the homologous gene of vertebrates. Proc Natl Acad Sci USA 77:2059

33. Shilo BZ, Weinberg RA (1981) DNA sequences homologous to vertebrate oncogenes are conserved in Drosophila melanogaster. Proc Natl Acad Sci USA 78:6789

34. Smart JE, Oppermann H, Czernilofsky AP, Purchio AF, Erikson RL, Bishop JM (1981) Characterization of sites for tyrosine phosphorylation in the transforming protein of Rous sarcoma virus (pp60\%-m) and its normal cellular homologue (pp606-re). Proc Natl Acad Sci USA 78:6013

35. Spector DH, Varmus HE, Bishop JM (1978) Nucleotide sequences related to the transforming gene of avian sarcoma virus are present in DNA of uninfected vertebrates. Proc Natl Acad Sci USA 75:4102

36. Spector DH, Baker B, Varmus HE, Bishop JM (1978) Characteristics of cellular RNA related to the transforming gene of avian sarcoma viruses. Cell 13:382

37. Spector DH, Smith K, Padgett T, McCombe P, RoullandDussoix D, Moscovici D, Varmus HE, Bishop JM (1978) Uninfected avian cells contain RNA related to the transforming gene of avian sarcoma virus. Cell 13:371

38. Stehelin D, Varmus HE, Bishop JM (1976) DNA related to the transforming gene (s) of avian sarcoma viruses is present in normal avian DNA. Nature 260:170

39. Ziemiecki A, Friis RR (1980) Simultaneous injection of newborn rabbits with the Schmidt-Ruppin and Prague strains of Rous sarcoma virus induces antibodies which recognize the pp60"e of both strains. J Gen Virol 50:211

40. Ziemiecki A, Bosch V, Bosch FX. Friis RR (to be published) Further analyses of several ts-td mutants of RSV showing separation of transformation parameters

Received August 1982 / Accepted in revised form October 1982 